\title{
Implication of Land-Use and Land-Cover Change into Carbon Dioxide Emissions in Karang Gading and Langkat Timur Wildlife Reserve, North Sumatra, Indonesia
}

\author{
Mohammad Basyuni ${ }^{1 *}$, Lollie Agustina Pancawaraswati Putri ${ }^{2}$, Muammar Bakar Murni ${ }^{1}$
}

${ }^{1}$ Faculty of Forestry, University of Sumatera Utara, Jl. Tri Dharma Ujung No. 1 Kampus USU Medan, Indonesia, 20155

${ }^{2}$ Faculty of Agriculture, University of Sumatera Utara, Jl. Prof. A. Sofyan No. 3 Kampus USU Medan, Indonesia 20155

Received March 3, 2015/Accepted April 25, 2015

\begin{abstract}
Mangrove forest in the context of climate change is important sector to be included in the inventory of greenhouse gas (GHG) emissions. The present study describes land-use and land-cover change during 2006-2012 of a mangrove forest conservation area, Karang Gading and Langkat Timur Laut Wildlife Reserve (KGLTLWR) in North Sumatra, Indonesia and their implications to carbon dioxide emissions. A land-use change matrix showed that the decrease of mangrove forest due to increases of other land-use such as aquaculture (50.00\%) and oil palm plantation (28.83\%). Furthermore, the net cumulative of carbon emissions in KGLTLWR for 2006 was 3804.70 t CO -eq year $^{-1}$, whereas predicting future emissions in 2030 was $11,318.74 \mathrm{t} \mathrm{CO}_{2}$-eq year ${ }^{-1}$ or an increase of $33.61 \%$ for 12 years. Source of historical emissions mainly from changes of secondary mangrove forests into aquaculture and oil palm plantation were 3223.9 t $\mathrm{CO}_{2}$-eq year ${ }^{-1}$ (84.73\%) and 959.00 t $\mathrm{CO}_{2}$-eq year ${ }^{-1}$ (25.21\%), respectively, indicating that the KGLTLWR is still a GHG emitter. Mitigation scenario with no conversion in secondary mangrove forest reduced $16.21 \%$ and $25.8 \%$ carbon emissions in 2024 and 2030, respectively. This study suggested that aquaculture and oil palm plantation are drivers of deforestation as well as the largest of GHG emission source in this area.
\end{abstract}

Keywords: carbon emission, climate change, deforestation, forest degradation, mangrove conservation

*Correspondence author, email: m.basyuni@usu.ac.id, tel.:+62-61-8201920,fax.: +62-61-8201920

\section{Introduction}

Indonesia is one of the world's great mangrove nations, which is $22.6 \%$ of the total global mangrove area. However, the Indonesian mangrove area has been degraded from 4.2 million in 1980 to only 3.1 million in 2011 (Giri et al. 2011). Mangrove forests are ecologically and economically important and among the most carbon-rich ecosystems in the tropics (Donato et al. 2011; Alongi 2014). Mangrove forest plays a vital role in the biogeochemical carbon cycle and climate regulation and to contributing potentially in reducing greenhouse gas emissions and facilitating counterbalance anthropogenic $\mathrm{CO}_{2}$ emissions (Bouillon 2011; Siikamaki et al. 2012; Alongi 2014). Mangrove forests in North Sumatra exist in the east coastal of Sumatra Island generally in Karang Gading and Langkat Timur Laut Wildlife Reserve (KGLTLWR) and are rapidly threatened due to anthropogenic activities such as conversion for aquaculture, oil palm plantation, filling and use of mangrove for urban development (Ilman et al. 2011; Basyuni et al. 2012, 2014).

Indonesia has declared its commitment to reduce emissions by $26-41 \%$ in 2020 (Boer et al. 2009). More than $50 \%$ of the emission reduction target is intended to come from the land-use, land-use-change and forestry sector (LULUCF). The conversion of tropical forest including mangrove forest led to increasing GHG emission by landuse/land-cover changes and the drivers of deforestation and forest degradation (DeFries \& Rosenzwig 2010; Miettinen et al. 2011; Houghton 2012; Margono et al. 2012). Due to large geographic coverage in Indonesia, potential reduced emissions from land-based sector are implemented in provincial and regency levels through Regional Action Plan for Greenhouse Gas Emissions Reduction (Rencana Aksi Daerah Penurunan Gas Rumah Kaca/RAD GRK)

Land-use and land-cover maps are fundamental towards coastal management planning and practice and systematic steps to calculate historical emissions, predicting future emissions as well as mitigating actions for emission reduction scenario by integrating land-based map and regional action plans (Prasetyo et al. 2008; Johana \& Agung 2011; Johana et al. 2013). Nonetheless, carbon emissions from mangrove forest conversion at regency level are poorly reported in Indonesia. In order to get more insight into the dynamic of mangrove ecosystem, setting the land-use policy and developing sustainable mangrove management in KGLTLWR, Deli Serdang and Langkat Regencies, North Sumatra Province, mapping and analyzing the land-use and land-cover change between 2006 and 2012 in relation to carbon dioxide emissions was attempted.

\section{Methods}

Study area The study was conducted in KGLTLWR, North Sumatra Province, a mangrove conservation forest covering 
area of about $13,431.96$ ha. The wildlife reserve is situated at $03^{\circ} 51^{\prime} 00^{\prime \prime}-03^{\circ} 59^{\prime} 45^{\prime \prime}$ North latitudes, and between at $98^{\circ}$ $30^{\prime}-98^{\circ} 42^{\prime}$ East longitudes (Figure 1). Regionally, KGLTLWR covers 2 regencies (kabupaten), namely Deli Serdang and Langkat, and 4 districts (kecamatan), namely Labuan Deli, Hamparan Perak, Tanjung Pura, and Secanggang. Formerly, the status of this site was as production forest with register $2 / \mathrm{L}$ according Deli Empire (Kesultanan Negeri Deli) Decision No. 148/PK, issued on August 6, 1932 and has been approved by the Governor of the Pesisir Timur Pulau Perca on 24 September 1932. The KGLTLWR was established under the Ministry of Agriculture Decree No. 811/Kpts/Um/11/1980, issued on November 5, 1980. The site was designed for mangrove flora and fauna conservation.

Dataset Land-use and land-cover data period 2006-2012 of KGLTLWR was obtained from Indonesia Republic of Ministry of Forestry (MoF), while Landsat 7 Enhanced Thematic Mapper Plus (ETM+) satellite image dated on July 24, 2006 and May 27, 2012 were acquired from USGS (http://glovis.usgs.gov/). The Regional Land-use Plan (Rencana Tata Ruang Wilayah/RTRW) map of North Sumatra Province provided the spatial planning zone of this wildlife reserve area year 2012 (dated on March 30, 2012) was derived from Development Planning Agency (Badan Perencanaan Pembangunan) of North Sumatra Province. A planning zone, basically denotes any land-use change process, was recorded and the zone contains factor affecting activity to develop appropriate mitigation actions. Zonation in this study is developed on spatial-based integration between various formal district planning documents such as the Long-Term Development Plan (Rencana Pembangunan Jangka Panjang/RPJP), Mid-Term Regional Development Plan (Rencana Pembangunan Jangka Menengah Daerah/RPJMD), Regional Government Work Plan (Rencana Kerja Pemerintah Daerah/RKPD), forestry land status (Tata Guna Hutan Kesepakatan/TGHK), land-use permits, and bio-physical elements (Johana et al. 2013). The KGLTLWR planning zone is depicted in Figure 2 and their definitions is shown in Table 1.

Analysis of land-use and land-cover changes Interpretation of the landsat images was conducted by applying supervised classification with maximum likelihood algorithm as previously reported (Donoghue \& Mironnet 2002). Image pre-processing, process of image interpretation, image classification, and change detections were performed by ERDAS Imagine 8.7 (ERDAS, Atlanta). Ground check was conducted by employing Global

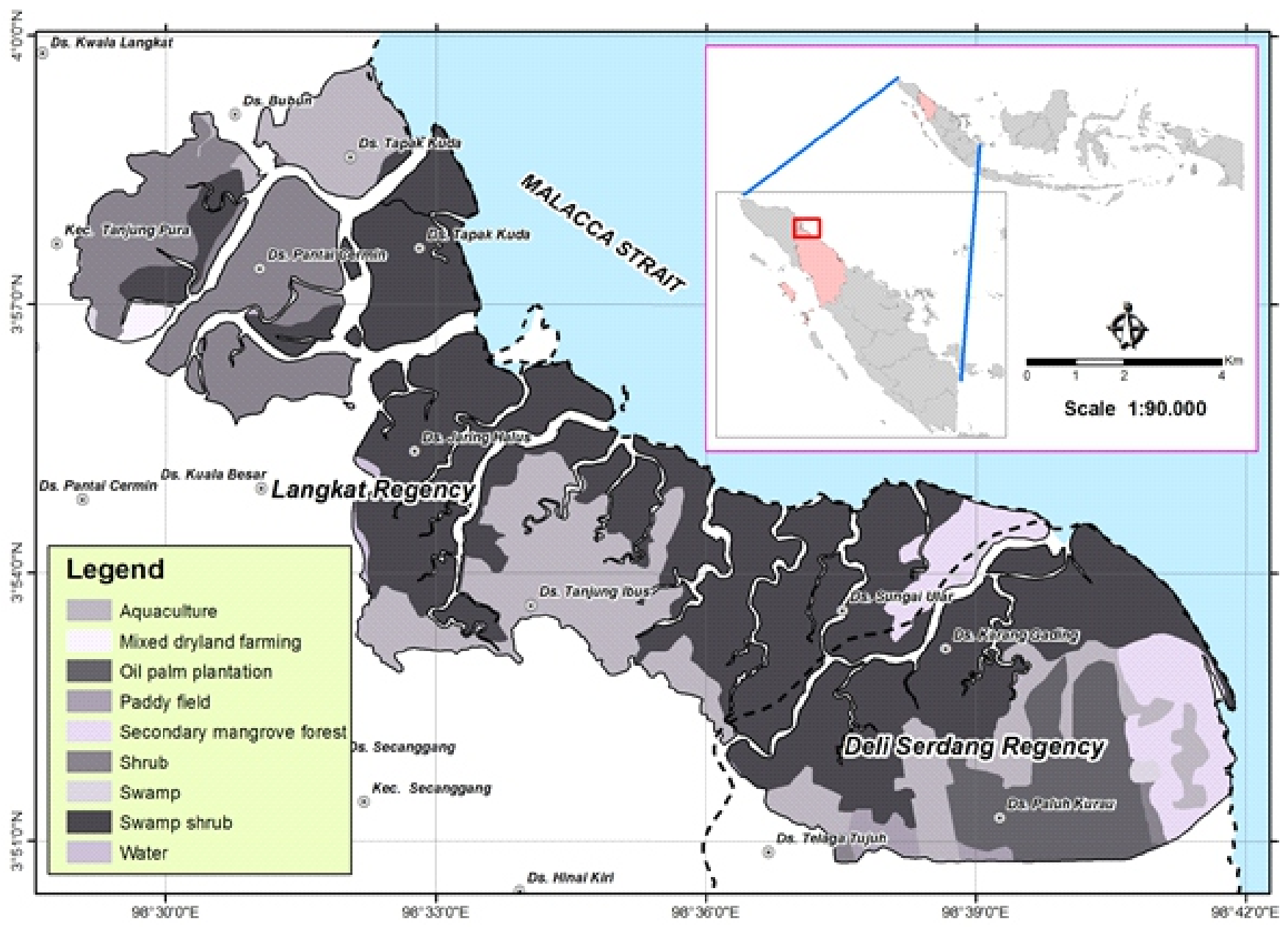

Figure 1 Location of study area. 


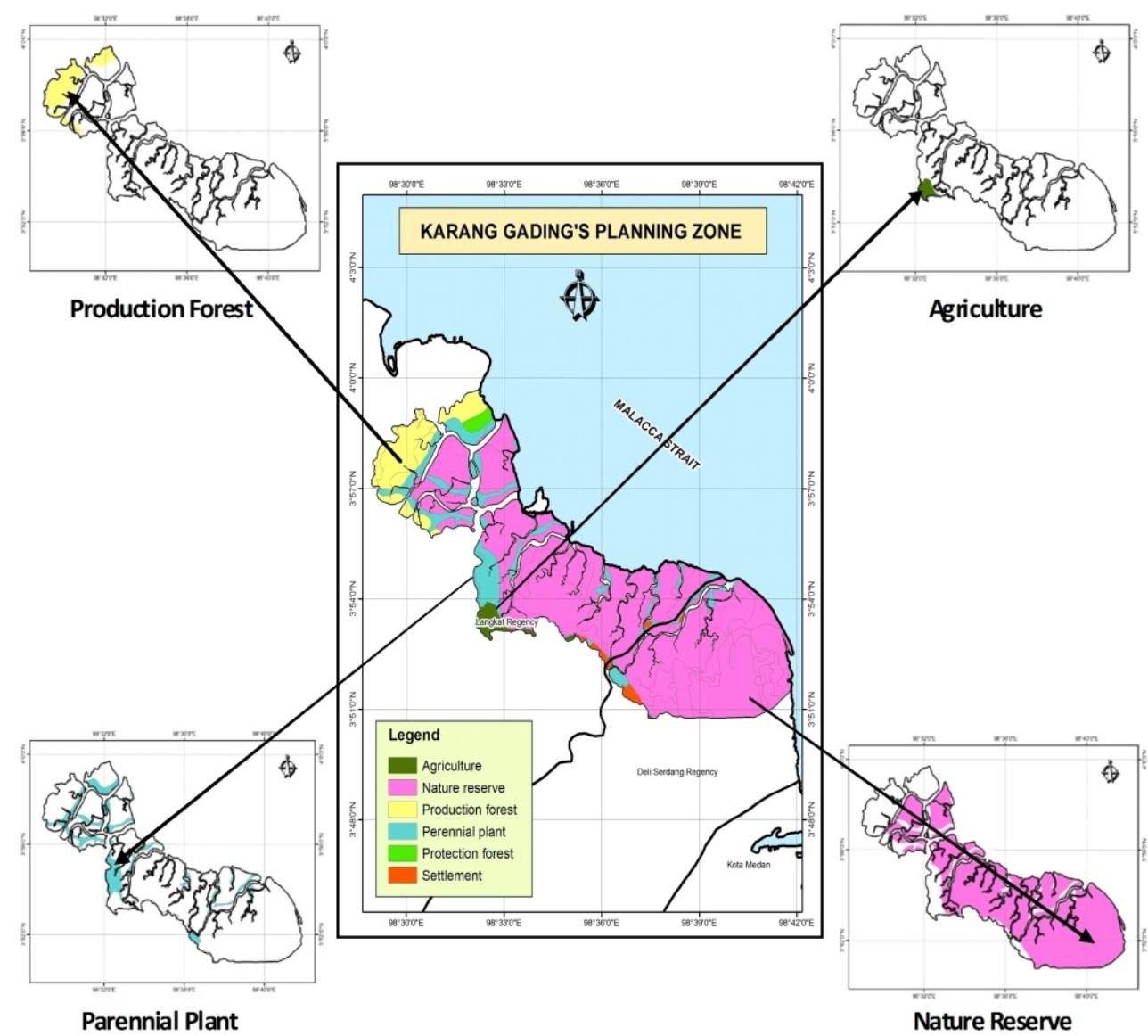

Figure 2 Map of KGLTLWR planning zone for estimating carbon emission and mitigation actions. Integrated map of landuse/land-cover and regional spatial land-use planning.

Table 1 Planning zone and general definition at Karang Gading and Langkat Timur Laut Wildlife Reserve

\begin{tabular}{lccl}
\hline \multicolumn{1}{c}{ Zone } & Width (ha) & Fraction (\%) & \multicolumn{1}{c}{ General definition } \\
\hline Protection forest & 116.57 & 0.87 & $\begin{array}{l}\text { An area of forest that the main function as life support system by } \\
\text { means of managing the water, control flooding and erosion, intrusion } \\
\text { of sea water and maintenance soil fertile. }\end{array}$ \\
Production forest & $1,174.99$ & 8.75 & $\begin{array}{l}\text { An area of forest that the main function to produce forest products. } \\
\text { This function is divided into two categories called definitive } \\
\text { production forest and limited production forest. }\end{array}$ \\
Nature reserve & $10,361.30$ & 77.14 & $\begin{array}{l}\text { An area with particular characteristic for biodiversity preservation of } \\
\text { flora, fauna and its ecosystem and also use as life support system. } \\
\text { An areal occupied by housing/permanent residents including road } \\
\text { networks and other facilities. } \\
\text { Anttlement }\end{array}$ \\
120.19 & 0.89 & 1.55 & $\begin{array}{l}\text { An area for production of food, feed, and fiber commodities, livestock } \\
\text { and poultry, bee. }\end{array}$ \\
Perennial plant & 208.40 & 10.80 & $\begin{array}{l}\text { An area consist of plant with a single, well defined stem carrying a } \\
\text { more-or-less-defined crown, including oil palm, rubber. }\end{array}$ \\
\hline Total & $1,450.51$ & 100.00 & \\
\hline
\end{tabular}


Positioning System (GPS) to collect information of recent land-use/land-cover. The information was used as guidance for image geometric correction and image rectification.

In order to increase size of the samples used in classification accuracy assessment, the layer with fieldchecked sites was then overlaid on the corrected satellite images, and uniform polygons with parallel spectral reflecting to be selected randomly in many of band combinations. The supervised classification also was supported by supplementary information from the digital land-use map, forest cover maps, Google Earth, and field survey data. The accuracy of classified map in this study was checked by the resultant layer of polygons (Donoghue \& Mironnet 2002).

The extensive field survey was carried out from July 5 to August 4, 2012 to verify ground truth points using the GPS. To improve the mapping accuracy, ecological information in a GIS package was combined with topological rules to the classified satellite data (Long \& Skewes 1996). A standard error matrix of classification validation was determined from the output map as the row and the ground truth points as the column in the matrix (Lunetta et al. 1991).

Geographic Information System (GIS) analysis was carried out by ArcGIS 9.3.1 and ArcView 3.3 (ESRI, USA). After accuracy assessment, the classified images were then exported to the GIS facilities to produce land-use and landcover map. Land-use and land-cover classifications in this study were taken from the MoF, Government of Indonesia published in 2012 containing 23 land-use/land-cover categories and 2006 Intergovernmental Panel on Climate Change (IPCC) Guidelines for National Greenhouse Gas Inventories Volume 4: Agriculture, Forestry and Other Landuse (IPCC 2006). However, minor modified was made to meet consistent land-use/land-cover categories accordingly. At last, 9 land-use/land-cover categories have been identified in this study. The land-use/land-cover classes consist of shrub, oil palm plantation, water, secondary mangrove forest, swamp shrub, mixed dryland farming, paddy field, aquaculture (tambak), and swamp. Their general description was summarized in Table 2 .

Field observations and carbon stock measurements In order to identify land-cover class in the study area, field observations in both Deli Serdang Regency and Langkat Regency were carried out. The information from the fields was used in coincidence with satellite imagery categories. GPS data were collected to create GPS coordinates for each class of land-use. The combination of various data such as land-cover data, structure and composition of existing species were purposely sampled. Furthermore the estimation of oil palm plantation and agriculture plant ages were made by interviewing with local communities. This information was important during land-use/land-cover classification of satellite imagery data (Prasetyo et al. 2008)

The biomass of each class of land-cover was measured using species-specific allometric equations with $d b h$ as the independent variable (Appendix Table 1), except for understorys and mixed agriculture plants, the biomass was measured using the harvest method. Position of understorys and mixed agriculture plants sampling within the plot of 200 $\mathrm{m}^{2}(5 \times 40 \mathrm{~m})$ that consisted of 5 plots. All vegetation less than $5 \mathrm{~cm} d b h$, herbs, grasses, flower, and fruits were harvested within $1 \times 1 \mathrm{~m}^{2}$, and then weighed fresh and weighed again after oven-draying as previously described (Hairiah et al. 2010). The carbon stock of each land-cover was determined by converting the biomass value into carbon stock by multiplying them by 0.5 (Laumonier et al. 2010; Saatchi et al. 2011). The carbon stock of land-use/land-cover in KGLTLWR used in this study is displayed in Table 3. Combination between transect and line compartment method was used for vegetation analysis (Kauffman \& Donato 2012).

Greenhouse gas (GHG) measurements and developing mitigation scenario The REDD Abacus SP software version 1.1.7 (Harja et al. 2011) developed by the World

Table 2 Land-use/land-cover classifiction and their general description

\begin{tabular}{ll}
\hline \multicolumn{1}{l}{ Land use/land cover } & General description \\
\hline Shrub & An area of land covered mainly with shrubby plants and/crops. \\
Oil palm plantation & A cultivating oil palm in the plantation area. \\
Water & An area covered by water such as ocean, river, estuarine. \\
Secondary mangrove forest & A mangrove forest that has been logged and has recovered naturally \\
& or artificially and forest cover has regenerated naturally or \\
& artificially through planting. \\
Swamp shrub & A type of freshwater wetland ecosystem occurring in areas too wet \\
& to forested swamps, but too dry or too shallow to be marshes. \\
Mixed dryland farming & An area cultivating a variety of food crop and vegetables. \\
Paddy field & A rice agriculture cultivating area. \\
Aquaculture & An area of traditional and modern fish and shrimp pond. \\
Swamp & An area of forested wetland, occuring along large rivers, covered by \\
& aquatic vegetation, or vegetation that tolerates periodical inundation.
\end{tabular}


JMHT Vol. XXI, (1): 25-35, April 2015

EISSN: 2089-2063

DOI: $10.7226 / \mathrm{jtfm} .21 .1 .25$

Appendix Table 1 Allomteric equations to determine biomass in this study

\begin{tabular}{|c|c|c|}
\hline Species & Equation & Reference \\
\hline \multirow[t]{2}{*}{ Rhizophora apiculata } & $\mathrm{AGB}=0.235 \mathrm{DBH}^{2.42}$ & Ong et al. 2004 \\
\hline & $\mathrm{BGB}=0.00698 \mathrm{DBH}^{2.61}$ & Ong et al. 2004 \\
\hline \multirow[t]{2}{*}{ R. mucronata } & $\mathrm{AGB}=0.128 \mathrm{DBH}^{2.60}$ & Fromard et al. 1998 \\
\hline & $\mathrm{BGB}=0.00974\left(\mathrm{DBH}^{2} \mathrm{H}\right)^{1.05}$ & Ong et al. 2004 \\
\hline \multirow[t]{2}{*}{ Exoecaria agallocha } & $\mathrm{AGB}=0.251 p \mathrm{DBH}^{2.46}$ from & Komiyama et al. 2008 \\
\hline & $\mathrm{BGB}=0.199 p 0.899 \mathrm{DBH}^{2.22}$ & Komiyama et al. 2008 \\
\hline \multirow[t]{2}{*}{ Sonneratia alba } & $\mathrm{AGB}=0.3841 p \mathrm{DBH}^{2.101}$ & Kauffman \& Donato 2012 \\
\hline & $\mathrm{BGB}=0.199 p 0.899 \mathrm{DBH}^{2.22}$ & Komiyama et al. 2008 \\
\hline \multirow[t]{2}{*}{ Avicennia alba } & $\mathrm{AGB}=0.251 p \mathrm{DBH}^{2.46}$ & Komiyama et al. 2008 \\
\hline & $\mathrm{BGB}=0.199 p 0.899 \mathrm{DBH}^{2.22}$ & Komiyama et al. 2008 \\
\hline \multirow[t]{2}{*}{ A. lanata } & $\mathrm{AGB}=0.251 p \mathrm{DBH}^{2.46}$ & Komiyama et al. 2008 \\
\hline & $\mathrm{BGB}=0.199 p 0.899 \mathrm{DBH}^{2.22}$ & Komiyama et al. 2008 \\
\hline \multirow[t]{2}{*}{ Aegiceras corniculatum } & $\mathrm{AGB}=0.251 p \mathrm{DBH}^{2.46}$ & Komiyama et al. 2008 \\
\hline & $\mathrm{BGB}=0.199 p 0.899 \mathrm{DBH}^{2.22}$ & Komiyama et al. 2008 \\
\hline \multirow[t]{2}{*}{ Bruguiera gymnorrhiza } & $\mathrm{AGB}=0.186 \mathrm{DBH}^{2.31}$ & Clough \& Scott 1989 \\
\hline & $\mathrm{BGB}=0.00188\left(\mathrm{DBH}^{2} \mathrm{H}\right)^{0.909}$ & Tamai et al. 1986 \\
\hline \multirow[t]{2}{*}{ B. parviflora } & $\mathrm{AGB}=0.168 \mathrm{DBH}^{2.42}$ & Clough \& Scott 1989 \\
\hline & $\mathrm{BGB}=0.00188\left(\mathrm{DBH}^{2} \mathrm{H}\right)^{0.909}$ & Tamai et al. 1986 \\
\hline \multirow[t]{2}{*}{ Xylocarpus granatum } & $\mathrm{AGB}=0.0823 \mathrm{DBH}^{2.59}$ & Clough \& Scott 1989 \\
\hline & $\mathrm{BGB}=0.145\left(\mathrm{DBH}^{2} \mathrm{H}\right)^{2.55}$ & Poungparn et al. 2002 \\
\hline Elaeis guineensis & $\mathrm{AGB}=0.0976 \mathrm{H}+0.0706$ & Hairiah et al. 2010 \\
\hline \multicolumn{3}{|c|}{ Note: $\mathrm{AGB}=$ above-ground biomass $(\mathrm{kg})$} \\
\hline \multicolumn{3}{|c|}{$\mathrm{BGB}=$ below-ground biomass $(\mathrm{kg})$} \\
\hline $\begin{aligned} \mathrm{DBH} & =\text { diameter } \\
p & =\text { wood dens } \\
\mathrm{H} & =\text { height }(\mathrm{m})\end{aligned}$ & ight $(\mathrm{cm})$ & \\
\hline
\end{tabular}

Table 3 Carbon stock of land use/land-cover in KGLTLWR

\begin{tabular}{lc}
\hline Land use/land-cover & Carbon stock $\left(\mathrm{t} \mathrm{ha}^{-1}\right)$ \\
\hline Shrub & 16.86 \\
Oil palm plantation & 22.96 \\
Secondary mangrove forest & 45.03 \\
Mixed dryland farming & 20.14 \\
Paddy field & 12.49 \\
Aquaculture & 10.30 \\
\hline
\end{tabular}


Agroforestry Center was used to measure the GHG emissions from land-use/land-cover of KGLTLWR. This carbon dioxide emission requires a dataset on carbon stock levels as emission factor for each land-use category (Table $3)$. Thus, the approach of emission was calculated from carbon stock difference in landscape level of land-use. As shown on Figure 2, integrating the development plan unit with the KGLTLWR land-use/land-cover enabled us to identify emission source, estimate the historical emissions, predict future emissions and determine emission, reduction scenario (Johana \& Agung 2011).

Developing mitigation scenario to reduce carbon dioxide emission was carried using the REDD Abacus SP software based on zones that significantly contributing to the emission, namely nature reserve (hutan suaka alam), where major land-use/land-cover changed in this study (Table 1, Figure 2). A step by step scenario was developed for the landuse of nature reserve, with the main activities to rule out land conversion from secondary mangrove forest through reforestation and rehabilitation activities.

\section{Results and Discussion}

Carbon stock estimation Concerning the carbon stock estimation of land-use/land-cover in this study is summarized in Table 3, it ranged 10.30-45.03 $\mathrm{t} \mathrm{C} \mathrm{ha}^{-1}$, with the highest and the lowest in secondary mangrove forest and aquaculture, respectively. On the other hand, intensive landuse such as oil palm plantation and mixed dryland farming had carbon stock half of secondary mangrove forest (Table 3 ). This result suggested maintaining the presence of secondary mangrove forest with relatively high carbon sequestration potency. Our result also supported previous reports that mangroves are among the most carbon-rich in the tropics, around $1,000 \mathrm{Mg} \mathrm{C} \mathrm{ha}^{-1}$ mostly derived from soil (600-700 Mg C ha-1), below ground (200 Mg C ha'), and above ground (100-150 $\mathrm{Mg} \mathrm{C} \mathrm{ha}^{-1}$ ) (Donato et al. 2011; Alongi 2014).
Land-use/land-cover changes between 2006 and 2012 The maximum likelihood supervised classification led to classify land-use/land-cover in KGLTLWR. The landuse/land-cover changes in KGLTLWR in period 2006-2012 are depicted on Figure 3 and Table 4. Our current study found 3 land-covers during 2006-2012, namely secondary mangrove forest, shrub, and swamp, decreased significantly by 213.62 ha (39.4\%), 31.47 (5.8\%), and 25.92 ha (19.29\%), respectively (Table 4). No change was noted in landuse/land-cover of water, swamp, shrub, and paddy field during 2006-2012 (Figure 3, Table 4).

Main changes of land-use/land-cover and their proportion is shown in Table 5. The total of 271.01 ha of land-cover was changed during 2006-2012 involved 5 landuse/land-cover change, i.e. shrub, secondary mangrove forest, swamp, oil palm plantation, and aquaculture. Secondary mangrove forest decreased dramatically, by as much as 216.62 ha, changed into aquaculture of 135.48 ha $(50.00 \%)$ and oil palm plantation of 78.14 ha $(28.83 \%)$. Shrub also contributed to the increase land-use of oil palm plantation of 31.47 ha $(11.61 \%)$. Whereas, swamp area as 25.92 ha $(9.56 \%)$ altered to aquaculture (Table 5$)$. On the other hand, in this wildlife reserve area, during 2006-2012, the increases of intensive land-use occurred, namely aquaculture of $161.39 \mathrm{ha}(59.56 \%)$ and oil palm plantation of 109.61 ha $(40.44 \%)$. Our current results drive some attentions with reference to the conversion of mangrove into intensive land-use during 2006-2012. There are some explanations. First, aquaculture and oil palm plantation were found as a main source of mangrove deforestation. Second, oil palm plantation grew very rapidly in the same period.

An analysis of agricultural and deforestation statistics for the period 1990-2005 showed that more than half of oil palm plantation in Indonesia including in North Sumatra had resulted in deforestation (Koh \& Wilcove 2008b). Our current results are consistent with previous report that agriculture expansion mainly oil palm estate has been shown as main driver of forest cover loss in Sumatra during 2000-2010 (Margono et al. 2012). Our findings also

Table 4 Land-use change matrix of KGLTLWR between 2006 and 2012

\begin{tabular}{|c|c|c|c|c|c|c|c|c|c|c|c|}
\hline & \multirow{2}{*}{$\begin{array}{l}\text { Land use/land-cover } \\
\text { classification }\end{array}$} & \multicolumn{10}{|c|}{ Land use 2012 (ha) } \\
\hline & & Shrub & $\begin{array}{l}\text { Oil palm } \\
\text { plantation }\end{array}$ & $\begin{array}{l}\text { Water } \\
\text { body }\end{array}$ & $\begin{array}{l}\text { Secondary } \\
\text { mangrove } \\
\text { forest }\end{array}$ & $\begin{array}{l}\text { Swamp } \\
\text { shrub }\end{array}$ & $\begin{array}{l}\text { Mixed } \\
\text { dryland } \\
\text { farming }\end{array}$ & $\begin{array}{l}\text { Paddy } \\
\text { field }\end{array}$ & Aquaculture & Swamp & Total \\
\hline \multirow{10}{*}{ 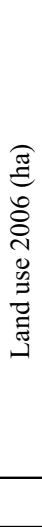 } & Shrub & $1,704.49$ & 31.47 & 0.00 & 0.00 & 0.00 & 0.00 & 0.00 & 0.00 & 0.00 & $1,735.96$ \\
\hline & Oil palm plantation & 0.00 & $1,061.24$ & 0.00 & 0.00 & 0.00 & 0.00 & 0.00 & 0.00 & 0.00 & $1,061.24$ \\
\hline & Water & 0.00 & 0.00 & 39.58 & 0.00 & 0.00 & 0.00 & 0.00 & 0.00 & 0.00 & 39.58 \\
\hline & Secondary mangrove forest & 0.00 & 78.14 & 0.00 & 644.49 & 0.00 & 0.00 & 0.00 & 135.48 & 0.00 & 858.11 \\
\hline & Swamp shrub & 0.00 & 0.00 & 0.00 & 0.00 & $6,697.76$ & 0.00 & 0.00 & 0.00 & 0.00 & $6,697.76$ \\
\hline & Mixed dryland farming & 0.00 & 0.00 & 0.00 & 0.00 & 0.00 & 63.51 & 0.00 & 0.00 & 0.00 & 63.51 \\
\hline & Paddy field & 0.00 & 0.00 & 0.00 & 0.00 & 0.00 & 0.00 & 131.04 & 0.00 & 0.00 & 131.04 \\
\hline & Aquaculture & 0.00 & 0.00 & 0.00 & 0.00 & 0.00 & 0.00 & 0.00 & $2,788.43$ & 0.00 & $2,788.43$ \\
\hline & Swamp & 0.00 & 0.00 & 0.00 & 0.00 & 0.00 & 0.00 & 0.00 & 25.92 & 30,40 & 56,32 \\
\hline & Total & $1,704.49$ & $1,170.85$ & 39.58 & 644.49 & $6,697.76$ & 63.51 & 131.04 & $2,949.82$ & 30,40 & $13,431,96$ \\
\hline
\end{tabular}




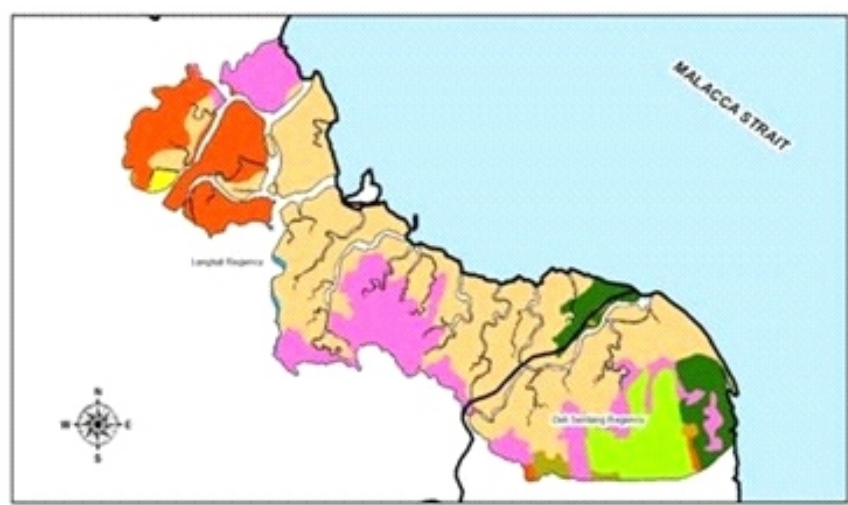

(a) 2006

Note:

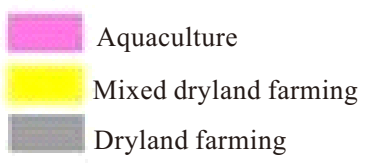

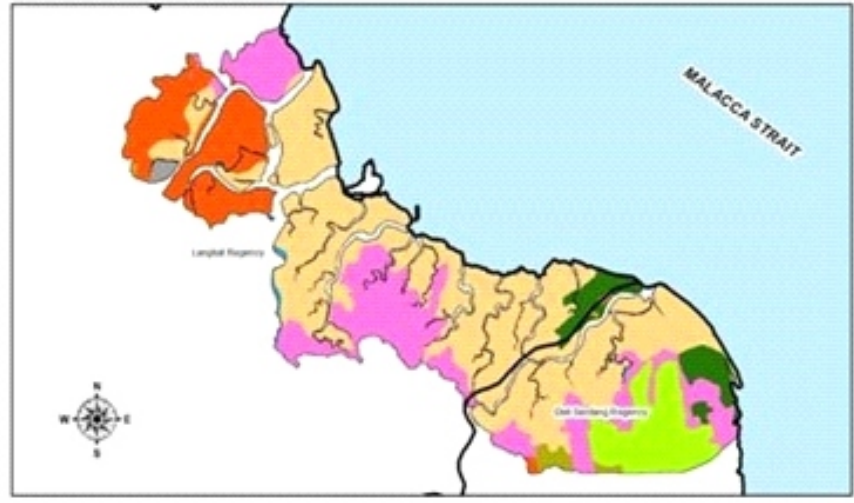

(b) 2012

Oilpalm plantation

Paddy field

Secondary mangrove forest

Shrub

Figure 3 Land use and land-cover of KGLTLWR between 2006 (a) and 2012 (b).

supported the previous report (Ramdani \& Hino 2013) that palm oil plantation was the main driving force of tropical deforestation at Riau Province in the early stages. Development of oil palm plantation in mangrove forest also was noted, however, the conversions area was small (Ramdani \& Hino 2013). Our findings were subsequently confirmed by time-series Landsat data that indicated the deforestation rate of mangrove forest during 2000-2005 was the highest in Indonesia $(0.75 \%)$, mainly because of the expansion aquaculture (63\%), agriculture (32\%), and urban development (5\%) (Giri et al. 2008). However, unlike in this study, conversion to agriculture is the major cause of mangrove deforestation in other areas of Asia such as Thailand (50\%), Burma (98\%), Bangladesh (77\%), India (50\%), and Sri Langka (92\%) (Giri et al. 2008).

Conversion to aquaculture is major cause of mangrove deforestation in Indonesia including in this study (Table 5). Shrimp aquaculture or fish pond has been one of the reasons for mangrove conversion (Primavera 2006). Capital investors have viewed mangrove forest as a common access resources and aquaculture as a means to increase their returns (Bosma et al. 2014). However, within some years of converting mangroves to shrimp pond, farmers have found their returns fallen as well as negative environmental impacts (Primavera 2006; Bosma et al. 2014). In this regards, several shrimp aquaculture either extensive or semi-extensive have been abandoned by the farmers in nature reserve zone of KGLTLWR. Moreover, conversion of mangrove forests to aquaculture in this area is without considering the fact that the total economic value of intact mangrove forests is often higher than that of shrimp farming (Balmford et al. 2002).

To create balance condition between conserving mangrove forest and offering better livelihood for local communities surrounding mangrove forest, silvofisheries (tambak tumpang sari) have been developed, especially in Java (Sukardjo 1989). The mixed mangrove-aquaculture on land managed by State Forest Corporation (PT Perhutani) to benefit rural communities, to increase mangrove plantation and to reduce erosion (Sukardjo 1989; Sutida 2000). It has been suggested by Primavera (2006) that mangroves and aquaculture are not necessarily incompatible. Such mangrove-friendly aquaculture is amenable to small-scale, family-based operation and may be adopted in mangrove conservation site (Primavera 2006). Silvofisheries may be applied in KGLTLWR especially in the zone of agriculture that consist of 208.40 ha (Table 1). In the mangrove-friendly aquaculture were planted with mangroves to provide firewood, fertilizers and protection from wave. The mixed mangrove-aquaculture system have various beneficial such as low capital provision, livelihood diversification through polyculture, provision of regular income and the recognition as an organic farming practice (Bosma et al. 2014).

Carbon dioxide emissions from KGLTLWR Mangroves are of particular importance for biogeochemical recycling of carbon and associated elements along the tropical coastal region. The findings of main drivers of forest cover loss, from land-use of aquaculture and oil palm plantation were paralleled with the net cumulative $\mathrm{CO}_{2}$ historical emissions detected during 2006-2012 (Table 6). Source of historical emissions mainly from the changes from secondary mangrove forests into aquaculture contributed of 3,223.9 t $\mathrm{CO}_{2}$-eq year ${ }^{-1}(84.73 \%)$, followed by changing of secondary mangrove forests into oil palm plantations of $959.00 \mathrm{t} \mathrm{CO}_{2}-$ eq year ${ }^{-1}(25.21 \%)$. This result indicates that the KGLTLWR is still a GHG emitter (Table 6). Furthermore our study suggested that aquaculture and oil palm plantation are driver of forest cover loss as well as the largest source of $\mathrm{CO}_{2}$-eq emissions in KGLTLWR.

It is also important to note that changes from shrub to oil palm plantation and swamp to aquaculture led negative net

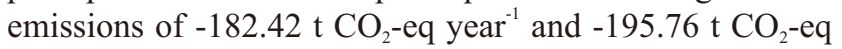


Table 5 Main changes of land use and land-cover and their proportion

\begin{tabular}{llcc}
\hline Land use (2006) & Land use (2012) & ha & Proportion (\%) \\
\hline Shrub & Oil palm plantation & 31.47 & 11.61 \\
Secondary mangrove forest & Oil palm plantation & 78.14 & 28.83 \\
& Aquaculture & 135.48 & 50.00 \\
Swamp & Aquaculture & 25.92 & 9.56 \\
Total & & 271.01 & 100.00 \\
\hline
\end{tabular}

Table 6 Net emission and their contribution from land use change between 2006 and 2012

\begin{tabular}{|c|c|c|c|}
\hline Land use (2006) & Land use (2012) & $\begin{array}{c}\text { Net emission } \\
\left(\mathrm{t} \mathrm{CO}_{2} \text {-eq year }{ }^{-1}\right)\end{array}$ & $\begin{array}{c}\text { Contribution } \\
(\%) \\
\end{array}$ \\
\hline Shrub & Oil palm plantation & -182.42 & -4.79 \\
\hline \multirow[t]{2}{*}{ Secondary mangrove forest } & Oil palm plantation & 959.00 & 25.21 \\
\hline & Aquaculture & $3,223.90$ & 84.73 \\
\hline Swamp & Aquaculture & -195.76 & -5.15 \\
\hline \multicolumn{2}{|c|}{ Total net emission ( $\mathrm{t} \mathrm{CO}_{2}$-eq year ${ }^{-1}$ ) } & $3,804.70$ & 100.00 \\
\hline \multicolumn{2}{|c|}{ Total net emission per ha ( $\mathrm{t} \mathrm{CO} 2$-eq ha ${ }^{-1}$.year) } & 0.2833 & \\
\hline
\end{tabular}

Note: Value of (-) was defined as sequestration

year $^{-1}$, respectively, suggesting palm trees and plants nearby aquaculture that used degraded lands absorbed the amount of $\mathrm{CO}_{2}$ through carbon sequestration (Table 6). The conversion of mangrove forest to aquaculture and oil palm estate greatly reduced forest biodiversity and carbon storage of forest biomass (Fitzherbert et al. 2008; Giri et al. 2008; Koh \& Wilcove 2008a,b). Therefore it has been suggested that the environmental and land-use tradeoffs related to oil palm estate expansion can be largely avoided through the implementation of a properly planned and spatially explicit development strategy (Koh \& Ghazoul 2010).

It has been reported that preventing mangrove loss has the potential of reducing global emissions for a cost of roughly at less than $\$ 10$ ton $^{-1} \mathrm{CO}_{2}$, where the Asia and Oceania region has the largest potential emissions offset supply (Siikamaki et al. 2012). This recent study suggested that protecting mangrove for their carbon was an economically feasible scheme (Siikamaki et al. 2012). In this context, Indonesia plays an important role to reduce GHG emission from mangroves, since largest mangrove area in the world existing in Indonesia.

Avoiding $\mathrm{CO}_{2}$ emission could be achieved through protection of mangroves to maintain biodiversity together with implementation of good policies and good institutions (Caldeira 2012). We therefore recommend a proposal to Natural Resources Conservation Offices (Balai Konservasi Sumberdaya Alam/BKSDA) at Deli Serdang and Langkat Regencies to implement a strict management of land conversion to protect this mangrove wildlife reserve area.

Developing scenario to reduce GHG emissions Developing mitigation scenario is important to determine activities that potentially contribute emissions reduction. Figure 4A shows GHG emission of business as usual (BAU) baseline without any intervention to climate change mitigation policy/technology. The approach was to set up the reference emission level using solely historical land-uses as the basis for predicting future emissions. The net cumulative of carbon dioxide emissions in KGLTLWR for 2006, 2012, 2018, and 2024 were 3804.70, 6664.96, 8750.29 and $10,250.55 \mathrm{t} \mathrm{CO}_{2}$-eq year ${ }^{-1}$, respectively. Whereas predicting future emissions in 2030 was $11,318.74 \mathrm{t} \mathrm{CO}_{2}$-eq year ${ }^{-1}$ or an increase of $33.61 \%$. The emission scenario was developed to reflect the mitigation action and for the purpose of calculating potential future emissions in the case of this study until 2030.

Mitigation scenario was modeled in nature reserve zone without conversion in the secondary mangrove forest (Figure 4B). Scenario takes place in the nature zone by preserving existing secondary mangrove forest and without conversion in secondary mangrove forest potentially reduced $5.99 \%$, $16.21 \%$, and $25.8 \%$ carbon dioxide emissions in 2018,2024 , and 2030 , respectively. A prohibition on the conversion of secondary mangrove forest to aquaculture or oil palm estate or other land-use is urgently required to preserve tropical biodiversity. A number of studies have been shown that oil palm plantation harbor far fewer forest-dwelling species than either primary or secondary forests (Fitzherbert et al. 2008; Koh \& Wilcove 2008a,b). Furthermore, the proper actions are needed to maintain the presence of secondary mangrove forest with a relatively high carbon sequestration potential and promoting rehabilitation programs in the region, especially in shrubs, barren land or an abandoned aquaculture.

Deforested and degraded mangrove areas can be rehabilitated and restored (Giri et al. 2008). Mangrove forest and coastal forest rehabilitation is therefore important efforts to restore within the framework of regional development (Kusmana et al.2005). The majority of agricultural areas and some of the aquaculture areas can be reforested. However, abandoned aquaculture areas are very difficult to rehabilitate or regenerate, mainly because of highly degraded by 


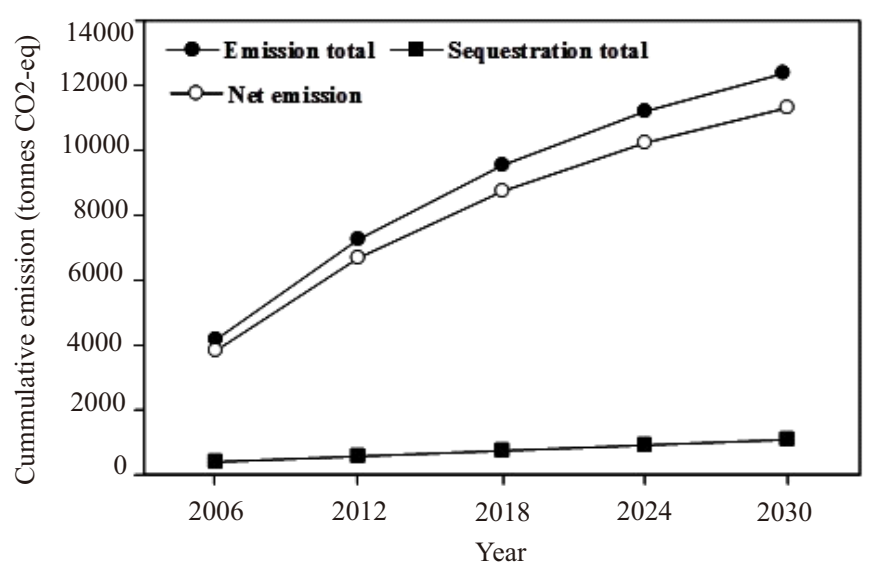

(a)

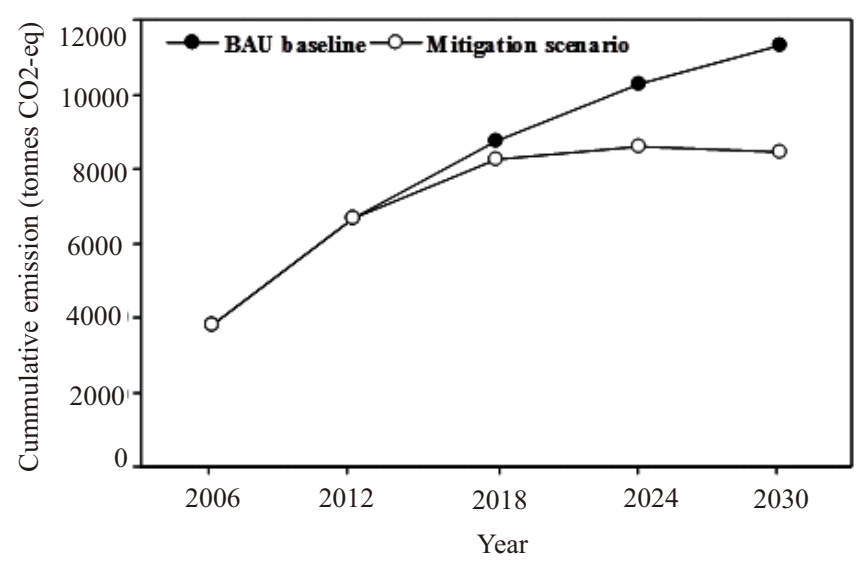

(b)

Figure 4 GHG emission of business as usual (BAU) baseline without any intervention to climate change mitigation. policy/technology (a) and mitigation scenario was modeled without conversion in the secondary mangrove forest (b).

pollution and pesticides (Giri et al. 2008). On the other hand, another scenario for emission reduction is applied by rehabilitating in nature reserve zone.

Vegetation analysis of KGLTLWR was found 10 species namely Rhizophora apiculata, R. mucronata, Excoecaria agallocha, Soneratia alba, Avicennia alba, A. lanata, Aegiceras corniculatum, Bruguiera gymnorriza, B. parviflora, and Xylocarpus granatum, which $R$. apiculata and E.agallocha were dominant species (data not shown). It has been reported for rehabilitation of degraded areas, main mangrove species planted in Indonesia were $B$. gymnorrhiza, $R$. apiculata, R. stylosa, and R. mucronata (Field 1998). Several mangrove and coastal forest tree species that are suitable for being planted in coastal areas in the case of tsunami-affected such as in Nanggroe Aceh Darussalam and Nias Island are exclusive mangrove species such as $R$. apiculata, $R$. stylosa, $R$. mucronata, Avicennia marina, A. lanata, A. alba, S. alba, Ceriops tagal, B. gymnorrhiza, Aegiceras floridum, mangrove associates (Osbornea octodonta, Scyphiphophora sp.) which also fit for mangrove forest area, and furthermore other species for example Casuarina equisetifolia, and Terminalia catappa for coastal forest area (Kusmana et al. 2005). It is therefore vital to emphasize the significance of identifying the aim of carrying out a rehabilitation program and to integrate such purposes with the welfare of local communities dependent on the mangrove ecosystem for sustenance (Field 1998). In this context to KGLTLWR, the reforestation and rehabilitation can be implemented successfully by using the recommended species for degraded areas and mangrove propagules or seeds are also available in the area.

Furthermore, in the forest area, land-uses were recommended in the form of green belt, while in non-forest area, alternative land-uses could also consider the aspect of land potency and aspiration of local community that have productive purposes, as well as conservation purposes, such as conducting the activities of silvofishery. Reductive activities were also recommended, such as the use of swamp for mangrove rehabilitation (Kusmana et al. 2005).

\section{Conclusion}

Strict management of land conversion is therefore needed to protect this mangrove conservation area and to maintain the presence of secondary mangrove forest with a relatively high carbon sequestration potential and promoting reforestation programs within the framework of regional development, especially in shrubs, barren land, or an abandoned aquaculture. Mitigation scenario with no conversion in secondary mangrove forest is potentially contributing to reduce carbon dioxide emissions in this reserve area. For the development of oil palm plantation in North Sumatra was recommended to use barren land or shrubs with low carbon potential and not to convert mangrove forests with a high carbon stock.

\section{Acknowledgement}

This study was supported by a Grant-in-Aid for a IbM (Ipteks bagi Masyarakat) Grant from the Directorate for Research and Community Service, Ministry of Education and Culture, Republic of Indonesia, a Development Grant from University of Sumatera Utara and from Japan International Cooperation Agency for the project "Regional Development Action Plan for Reducing Greenhouse Gas Emissions of North Sumatra". The authors are grateful to M Kholis Hamdy, Jaka Prawira, Harry Kurniawan, Dian Novitasari, Tetty Hutabarat, Putri Sihaloho and Berliana Nainggolan for field assistance.

\section{References}

Alongi DM. 2014. Carbon cycling and storage in mangrove forests. Annual Review of Marine Science 6:195-219. http://dx.doi.org/10.1146/annurev-marine-010213135020 .

Balmford A, Bruner A, Cooper P, Costanza R, Farber S, Green RE, Jenkins M, Jefferiss P, Jessamy V, Madden J, Munro K, Myers N, Naeem S, Paavola J, Rayment M, Rosendo S, Roughgarden J, Trumper K, Turner RK. 2002. Economic reasons for conserving wild nature. Science 297:950-953. http://dx.doi.org/10.1126/science. 
1073947

Basyuni M, Putri LAP, Julayha, Nurainun H, Oku H. 2012. Non-saponifiable lipid composition of four salt-secretor and non-secretor mangrove species from North Sumatra, Indonesia. Makara Journal of Science 16:89-94. http://dx.doi.org/10.7454/mss.v16i2.1402.

Basyuni M, Putri LAP, Nainggolan B, Sihaloho PE. 2014. Growth and biomass in response to salinity and subsequent fresh water in mangrove seedlings Avicennia marina and Rhizophora stylosa. Jurnal Manajemen Hutan Tropika 20:17-25. http://dx.doi.org/10. 7226/jtfm.20.1.17.

Bosma RH, Nguyen TH, Siahainenia AJ, Tran HTP, Tran HN. 2014. Shrimp-based on livelihoods in mangrove silvoaquaculture farming systems. Reviews in Aquaculture 6:1-18. http://dx.doi.org/10.1111/raq.12072.

Boer R, Sulistyowati, Las I, Zed F, Masripatin N, Kartakusuma DA, Hilman D, Mulyanto HS. 2009. Summary for Policy Makers: Indonesia Second National Communication Under The United Nations Framework Convention on Climate Change (UNFCCC). Jakarta: Ministry of Environment.

Bouillon S. 2011. Carbon cycle: storage beneath mangroves. Nature Geoscience 4:282-283. http://dx.doi.org/10. 1038/ngeo1130.

Caldeira K. 2012. Avoiding mangrove destruction by avoiding carbon dioxide emissions. Proceedings of the National Academy of Sciences USA 109:14287-14288. http://dx.doi.org/10.1073/pnas.1211718109.

Clough BF, Scott K. 1989. Allometric relationship for estimating above-ground biomass in six mangrove species. Forest Ecology and Management 27:117-127. http://dx.doi.org/10.1016/0378-1127(89)90034-0.

DeFries R, Rosenzweig C. 2010. Toward a whole-landscape approach for sustainable land-use in the tropics. Proceedings of the National Academy of Sciences USA 107:19627-19632. http://dx.doi.org/10.1073/pnas. 1011163107.

Donato DC, Donato DC, Kauffman JB, Murdiyarso D, Kurnianto S, Stidham M, Kanninen M. 2011. Mangroves among the most carbon-rich forests in the tropics. Nature Geoscience 4:293-297. http://dx.doi.org/10.1038 /ngeo1123.

Donoghue DNM, Mironnet N. 2002. Development of an integrated geopgraphical information system prototype for coastal habitat monitoring. Computer \& Geosciences 28:129-141. http://dx.doi.org/10.1016/S0098-3004(01) 00021-8.

Field CD. 1998. Rehabilitation of mangrove ecosystems: an overview. Marine Pollution Bulletin 37:383-392. http://dx.doi.org/10.1016/S0025-326X(99)00106-X.
Fitzherbert EB, Struebig MJ, Morel A, Danielsen F, Bruhl CA, Donald PF, Phalan B. 2008. How will oil palm expansion affect biodiversity? Trends in Ecology and Evolution 23:538-545. http://dx.doi.org/10.1016/j.tree. 2008.06.012.

Fromard F, Puig H, Mougin E, Marty G, Betoulle JL, Cadamuro L. 1998. Structure above-ground biomass and dynamics of mangrove ecosystems: new data from French Guiana. Oecologia 115:39-53. http://dx.doi.org/ $10.1007 /$ s004420050489.

Giri C, Zhu Z, Tieszen LL, Singh A, Gillette S, Kelmelis JA. 2008. Mangrove forest distributions and dynamics (1975-2005) of the tsunami-affected region of Asia. Journal of Biogeography 35:519-528. http://dx.doi. org/10.1111/j.1365-2699.2007.01806.x.

Giri C, Ochieng E, Tieszen LL, Zhu Z, Singh A, Loveland T, Masek J, Duke N. 2011. Status and distribution of mangrove forests of the world using earth observation satellite data. Global Ecology and Biogeography 20:154-159. http://dx.doi.org/10.1111/j.1466-8238. 2010.00584.x.

Hairiah K, Dewi S , Fahmuddin A, Velarde S, Ekadinata A, Subekti R, van Noordwijk M. 2010. Measuring Carbon Stocks Across Land-use Systems: A Manual. Bogor: World Agroforestry Centre-ICRAF.

Harja D, Dewi S, van Nordwijk M, Ekadinata A, Rahmanulloh A. 2011. REDD Abacus SP-User Manual and Software. Bogor: World Agroforestry CenterICRAF

Houghton RA. 2012. Carbon emissions and the drivers of deforestation and forest degradation in the tropics. Current Opinion in Environmental Sustainability 4:597-603. http://dx.doi.org/10.1016/j.cosust.2012. 06.006.

Ilman M, Wibisono ITC, Suryadiputra INN. 2011. State of the Art Information on Mangrove Ecosystems in Indonesia. Bogor: Wetland International-Indonesia Programme.

[IPCC] Intergovernmental Panel on Climate Change. 2006. IPCC Guidelines for National Greenhouse Gas Inventories. Japan: IGES.

Johana F, Agung P. 2011. Planning for Low-Emissions Development in Merangin District, Jambi Province, Indonesia. Brief No 19. Bogor: World Agroforestry Centre-ICRAF.

Johana F, Suyanto S, Widayati A, Zulkarnain MT, Muller D, Budiman A. 2013. Local Mitigation Actions Supporting The low Emission Development Plan in Kutai Barat District, Indonesia-Initial Process. Brief No. 35. Bogor: World Agroforestry Centre-ICRAF.

Kauffman JB, Donato DC. 2012. Protocols for the 
Measurement, Monitoring and Reporting of Structure, Biomass and Carbon Stocks in Mangrove Forests. Working Paper 86. Bogor: Center for International Forestry Research.

Koh LP, Wilcove DS. 2008a. Oil palm: disinformation enables deforestation. Trends in Ecology and Evolution 24:67-68. http://dx.doi.org/10.1016/j.tree.2008.09.006.

Koh LP, Wilcove DS. 2008b. Is oil palm agriculture really destroying tropical biodiversity? Conservation Letters 1:60-64. http://dx.doi.org/10.1111/j.1755-263x.2008. 00011.x.

Koh LP, Ghazoul J. 2010. Spatially explicit scenario analysis for reconciling agricultural expansion, forest protection, and carbon conservation in Indonesia. Proceedings of the National Academy of Sciences USA 107: 11140-11144. http://dx.doi.org/10.1073/pnas.1000530107.

Komiyama A, Ong JE, Poungparn S. 2008. Allometry, biomass, and productivity of mangrove forests: A review. Aquatic Botany 89:128-137. http://dx.doi.org/10. 1016/j.aquabot.2007.12.006.

Kusmana C, Basuni S, Wilarso S, Ichwandi I, Haridjaja O, Soleh A, Samsuri. 2005. Directives for mangrove forest and coastal forest rehabilitation in earthquake and tsunami disaster area in the provinces of Nanggroe Aceh Darussalam and Sumatera Utara (Nias Island), Indonesia. Jurnal Manajemen Hutan Tropika 11(2):70-84.

Laumonier Y, Edin A, Kanninen M, Munandar AW. 2010. Landscape-scale variation in the structure and biomass of the hill dipterocarp forest of Sumatra: implication for carbon stock assessments. Forest Ecology and Management 259:505-513. http://dx.doi.org/10.1016/ j.foreco.2009.11.007.

Long BG, Skewes TD. 1996. A technique for mapping mangroves with Landsat TM satellite data and geographic information system. Estuarine, Coastal and Shelf Science 43:373-381. http://dx.doi.org/10.1006/ ecss.1996.0076.

Lunetta RS, Congalton RG, Fenstermaker LK, Jensen JR, McGwire KC, Tinney LR . 1991. Remote sensing and Geographic Information System data integration: error sources and research issues. Photogrammetric Engineering and Remote Sensing 57: 677-687.

Margono BA, Turubanova S, Zhuravleva I, Potapov P, Tyukavina A, Baccini A, Goetz S, Hansen MC. 2012. Mapping and monitoring deforestation and forest degradation in Sumatra (Indonesia) using Landsat time series data sets from 1990 to 2010. Environmental Research Letter 7:034010. http://dx.doi.org/10.1088/ $1748-9326 / 7 / 3 / 034010$.
Miettinen J, Shi CG, Liew SC. 2011. Deforestation rate in insular Southeast Asia between 2000 and 2010. Global Change Biology 17:2261-2270. http://dx.doi.org/10. 1111/j.1365-2486.2011.02398.x.

Ong JE, Gong WK, Wong CH. 2004. Allometry and partitioning of the mangrove, Rhizophora apiculata. Forest Ecology and Management 188:395-408. http://dx.doi.org/10.1016/j.foreco.2003.08.002.

Poungparn S, Komiyama A, Jintana V, Piriyayaota S, Sangtiean T, Tanapermpool P, Patanaponpaiboon P, Kato S. 2002. A quantitative analysis on the root system of a mangrove, Xylocarpus granatum Koenig. Tropics 12: 35-42. http://dx.doi.org/10.3759/tropics.12.35.

Prasetyo LB,Wibowo SA, Kartodihardjo H, Tonny F, Haryanto, Sonaji R, Setiawan Y. 2008. Land-use and land-cover changes of conservation area during transition to regional autonomy: case study of Balairaja Wildlife Reserve in Riau Province, Indonesia. Tropics 17: 99-108. http://dx.doi.org/10.3759/tropics.17.99.

Primavera JH 2006. Overcoming the impacts of a aquaculture on the coastal zone. Ocean \& Coastal Management 49:531-545. http://dx.doi.org/10.1016/j. ocecoaman.20 06.06.018.

Ramdani F, Hino M. 2013. Land-use changes and GHG emissions from tropical forest conversion by oil palm plantations in Riau Provinces, Indonesia. Plos One 8:e770323. http://dx.doi.org/10.1371/journal.pone. 0070323 .

Saatchi, Harris NL, Brown S, Lefsky M, Mitchard ETA, Salas W, Zutta BR, Buermann W, Lewis SL, Hagen S, Petrova S, White L, Silman M, Morel A. 2011. Benchmark map of forest carbon stocks in tropical regions across three continents. Proceedings of the National Academy of Sciences USA 108:9899-9904. http://dx.doi.org/10.1073/pnas.1019576108.

Siikamaki J, Sanchirico N, Jardine SJ. 2011. Global economic potential for reducing carbon dioxide emissions from mangrove loss. Proceedings of the National Academy of Sciences USA 109: 14369-14374. http://dx.doi.org/10.1073/pnas. 1200519109.

Sukardjo S. 1989. Tumpang sari pond as a multiple use concept to save the mangrove forest in Java. Biotrop Special Publication 37:115-128.

Surtida MB. 2000. Silvofisheries in Indonesia. SEAFDEC Asian Aquaculture 22:20-28.

Tamai S, Nakasuga T, Tabuchi R, Ogino K. 1986. Standing biomass of mangrove forests in southern Thailand. Journal of Japanese Forest Society 68: 384-388. 